\title{
Title
}

\section{Genetic Music: when genes code for melodies instead of proteins}

Authors: MARGA Consortium¹, Blanca A. Gutiérrez², Iván Aitor Lucas-del Amo², Beatriz Alejos-Bermúdez², Cristina González-Morán², Verónica Noval-Gutiérrez², Borja Sánchez ${ }^{2 *}$

1. Musicians And Resilient Geneticists of Asturias

2. Ministry of Science, Innovation and University. Government of the Principality of Asturias. C/Trece Rosas, no 2-33005 Oviedo, Principality of Asturias.

Corresponding author: ciencia@asturias.org

\begin{abstract}
In the present work we present a methodology for teaching the basis of the genetic code through music composition, with the aim to combine science and arts learning. The project was carried out by 155 students, the so-called MARGA Consortium, with ages comprised between 10 and 17 years from different public schools located in the Principality of Asturias, Spain. The different groups generated 8 different music works using a short genetic sequence obtained from the human notch1 gene, receptor of mutations leading to chronic lymphocytic leukemia.
\end{abstract}

Keywords: genetic music, genetic code, music composition, steam disciplines, notch1 gene 


\section{Introduction and methodology}

If something should characterize STEAM education is driving students to the exploration of intersections between different disciplines while fostering both creativity and innovation. In this way young scholars can discover how the different areas of knowledge are not isolated but connected. This was our aim with the project Genetic Music (In spanish, Música Genética), developed in the Principality of Asturias, Spain, during the Week of Science and Technology (November $14^{\text {th }}, 2019$ ).

Our main goal was to develop a methodology for the simultaneous teaching of the genetic code using a music composition technique. The process was implemented as follows. Each group of students, representing the 8 public schools involved in the project, was provided with an empty "Genetic Music Card" (Figure 1). The card contained a little introduction to the methodology, which contained basically a protocol to transform DNA triplets into musical notes.

Before working with the students, music and biology teachers were introduced to the methodology, and afterwards they were the responsible to organize the rest of the work. An example of completed card is presented in Figure 1. Students filled out the empty codon table corresponding to the genetic code using musical notes instead of amino acids. Afterwards, the small sequence from the human notch1 gene was transcribed into notes using triplets, from left to the right, i.e. following the usual $\quad 5^{\prime} \quad 3^{\prime}$ direction: ACTAGTGCCTCGGCCGCGGGAGGGAGCGCAAGGGCGCGGGGC.

Figure 1. Methodology of the Genetic Music Project. The last slide shows an example of a completed card with a genetic melody.

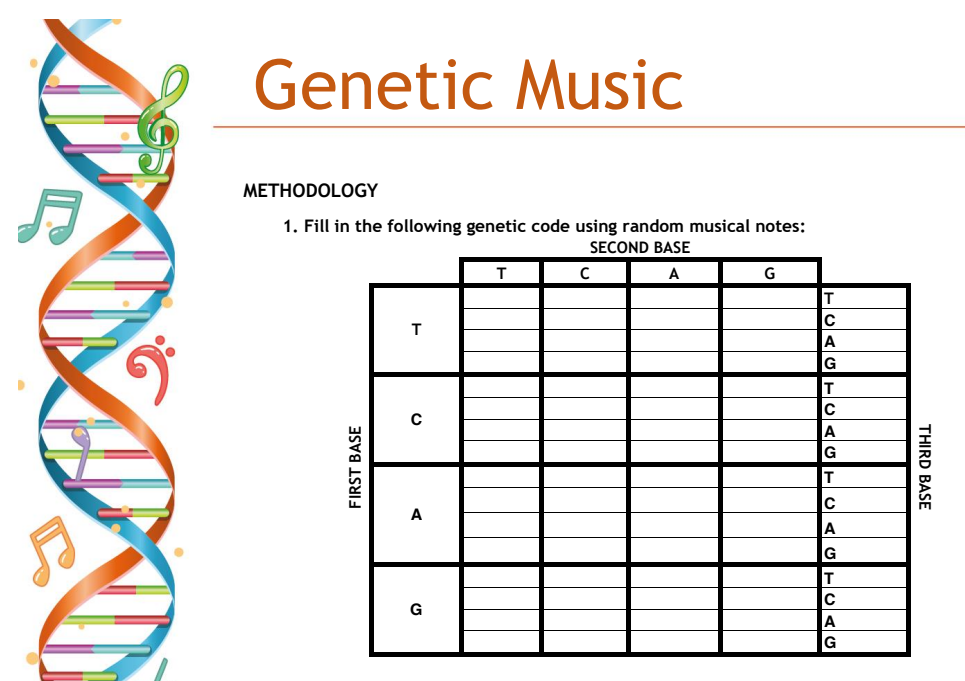



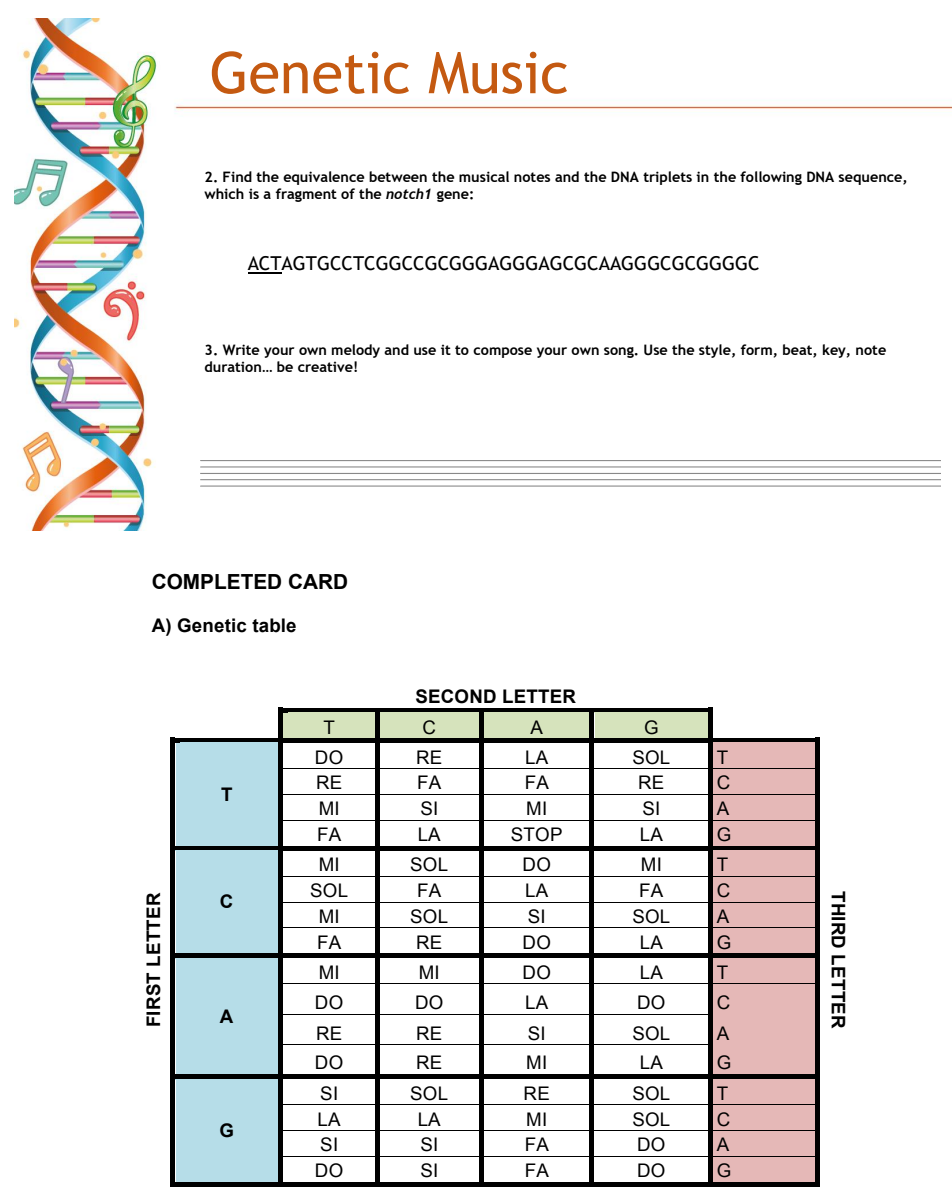

B) Notch1 gene fragment and resulting melody

ACT-AGT-GCC-TCG-GCC-GCG-GGA-GGG-AGC-GCA-AGG-GCG-CGG-GGC

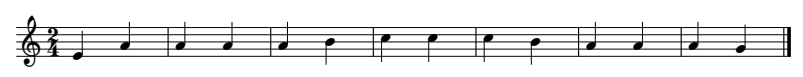

Notch1 gene was chosen as several mutations located in this gene appear recurrently in chronic lymphocytic leukemia (CLL) patients, the most common leukemia type in adults [1]. In our particular example, the aim underlying using notch1 gene was to raise awareness about how science is helping us to fight against cancer, but genetic music can serve to visualize the scientific efforts against other diseases by choosing other relevant genes. The melodic motif of 14 notes generated with the notch1 gene fragment was employed by the students to create and orchestrate their own compositions with the help of their teachers.

Table 1. School names and demographic data of the children participating in this project. Grades are defined according to the actual Spanish legislation.

\begin{tabular}{|c|c|c|c|c|}
\hline School & City & Grade & Age & $\mathrm{N}$ \\
\hline CP La Ería & Oviedo & 60 Primaria & $11-12$ & 37 \\
\hline IES Aramo & Oviedo & 1ㅇ Bachiller & $16-17$ & 5 \\
\hline IES Isla de la Deva & Piedras Blancas & 1 $E S O$ & $12-13$ & 12 \\
\hline IES Río Trubia & Oviedo & $2^{\circ}=E S O$ & $13-14$ & 17 \\
\hline IES Padre Feijóo & Gijón & $2^{\circ} \mathrm{ESO}$ & $13-14$ & 18 \\
\hline IES Bernaldo de Quirós & Mieres & 1ㅇ Bachiller & $16-17$ & 2 \\
\hline IES Infiesto & Infiesto & $2^{\circ} \mathrm{ESO}$ & $13-14$ & 27 \\
\hline CP Darío Freán Barreira & Jarrio & 5-6ㅇ Primaria & $10-12$ & 37 \\
\hline
\end{tabular}




\section{Results}

The outcomes of the different student groups involved in the project are shown next. Many groups obtained a series of melodies after filling out the genetic card, and then these melodies were played at the unison (Figures 2-6).

Figure 2. Melody from CP La Ería (37 students)

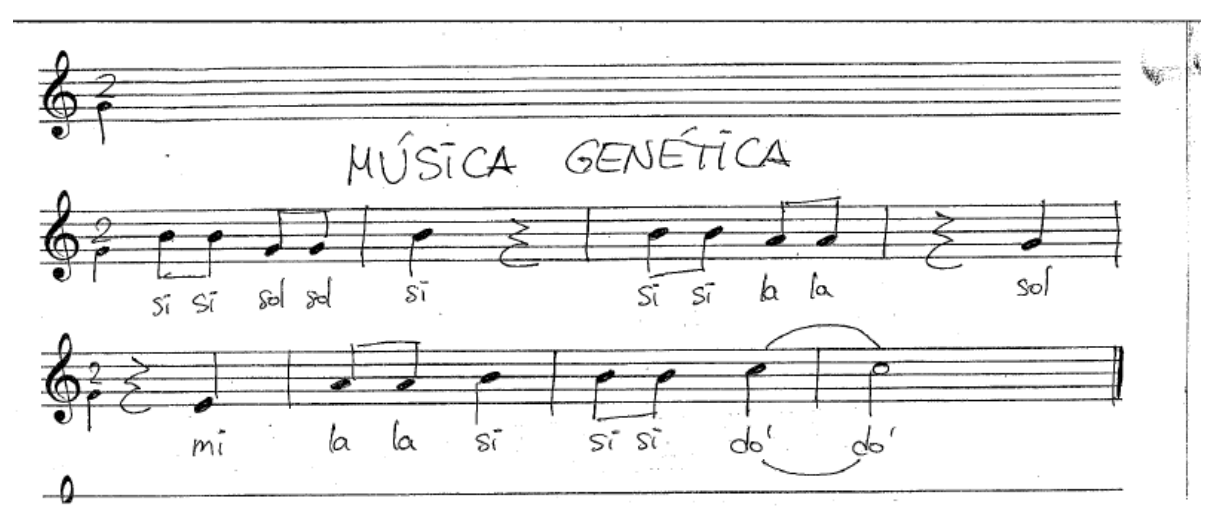

Figure 3. Melody from IES Aramo (5 students)

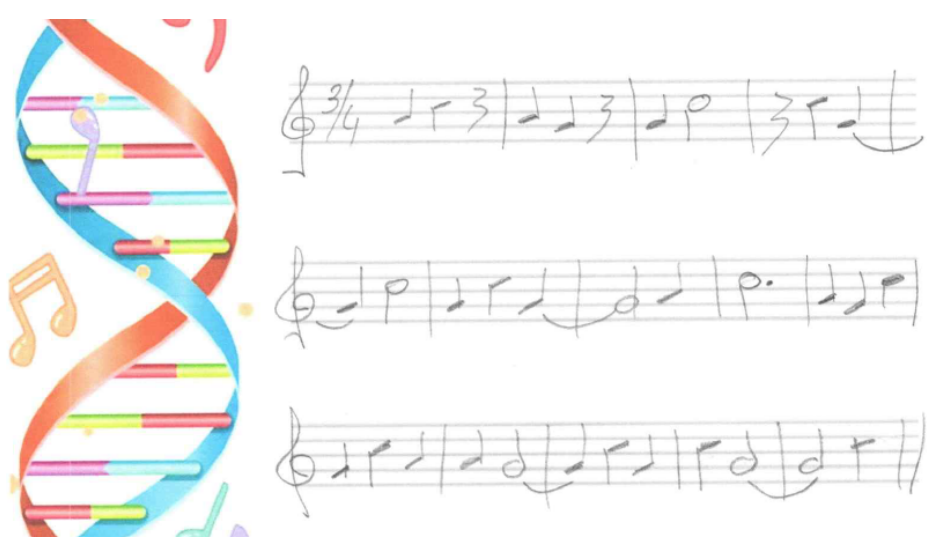

Figure 4. Melody from IES Padre Feijóo (18 students)

Notch 1 Tema $2+$ Coda

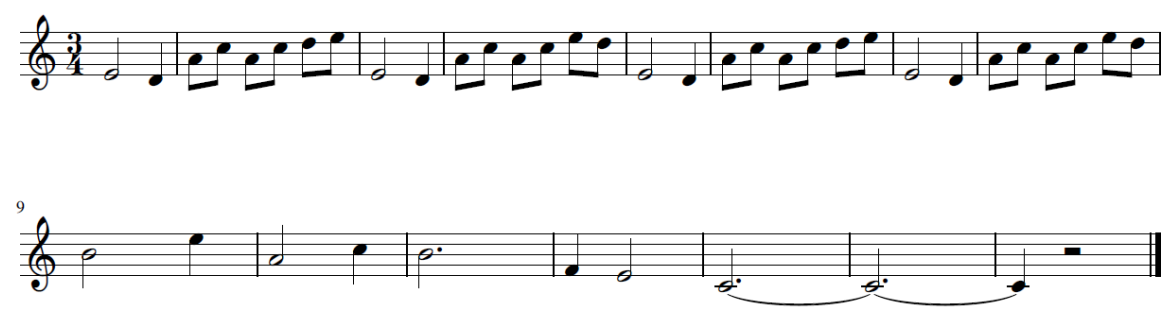


Figure 5. Melody from IES Río Trubia (17 students)

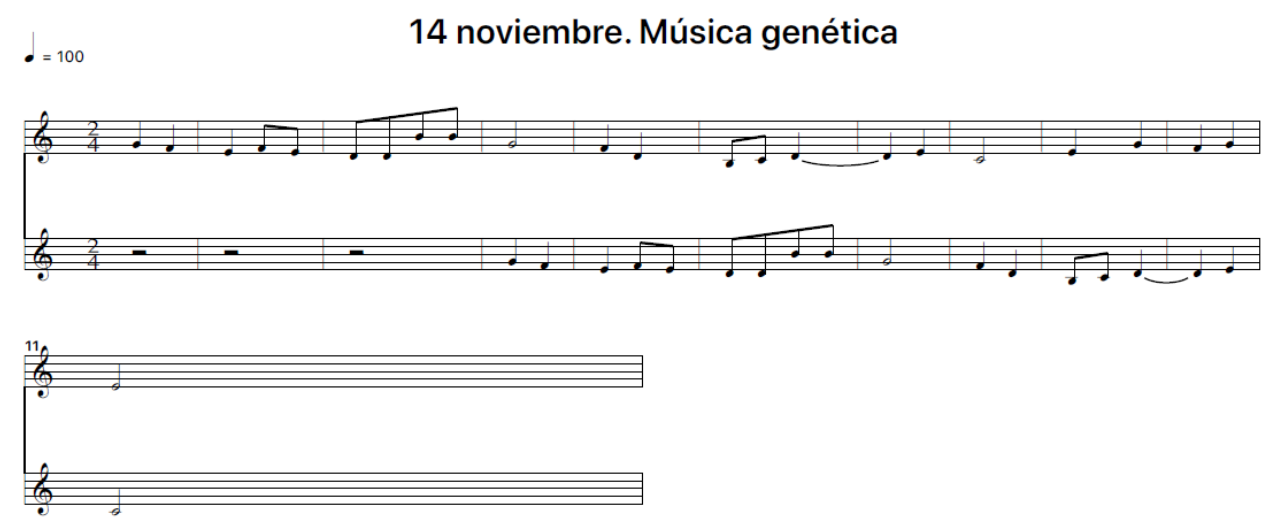

Figure 6. Melody from IES Infiesto (27 students)
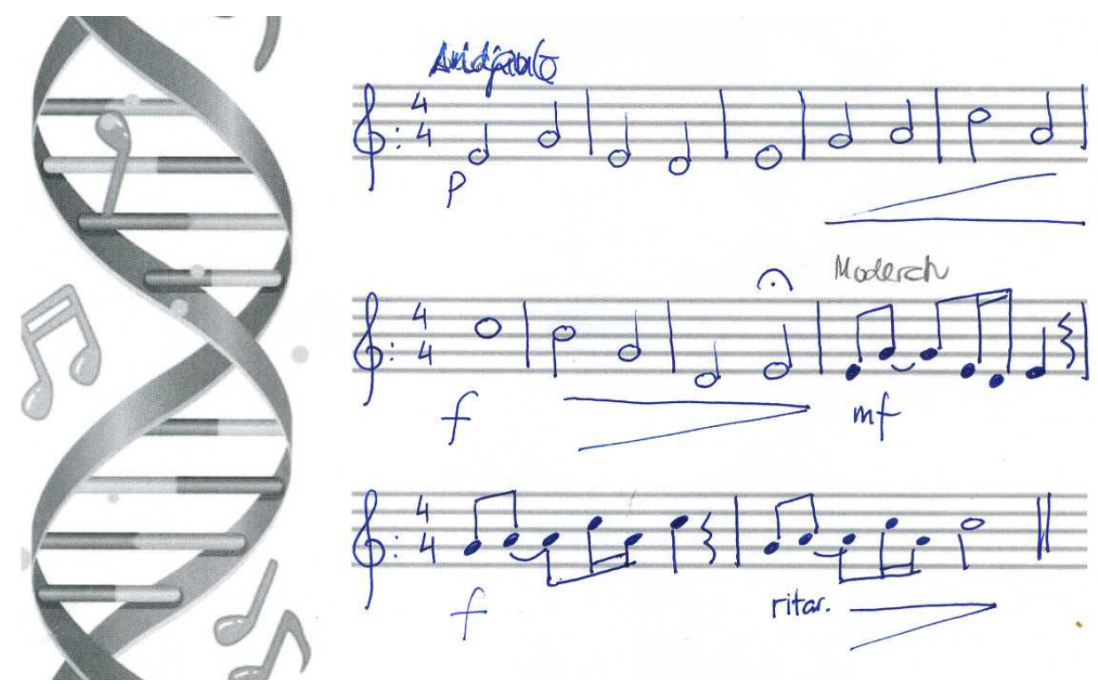

Three out of the 8 groups arranged the melodies into different musical settings (Figures 7-9). Figure 7 showed the score from IES Isla de la Deva (12 students), including the melody with an harmonic piano base.

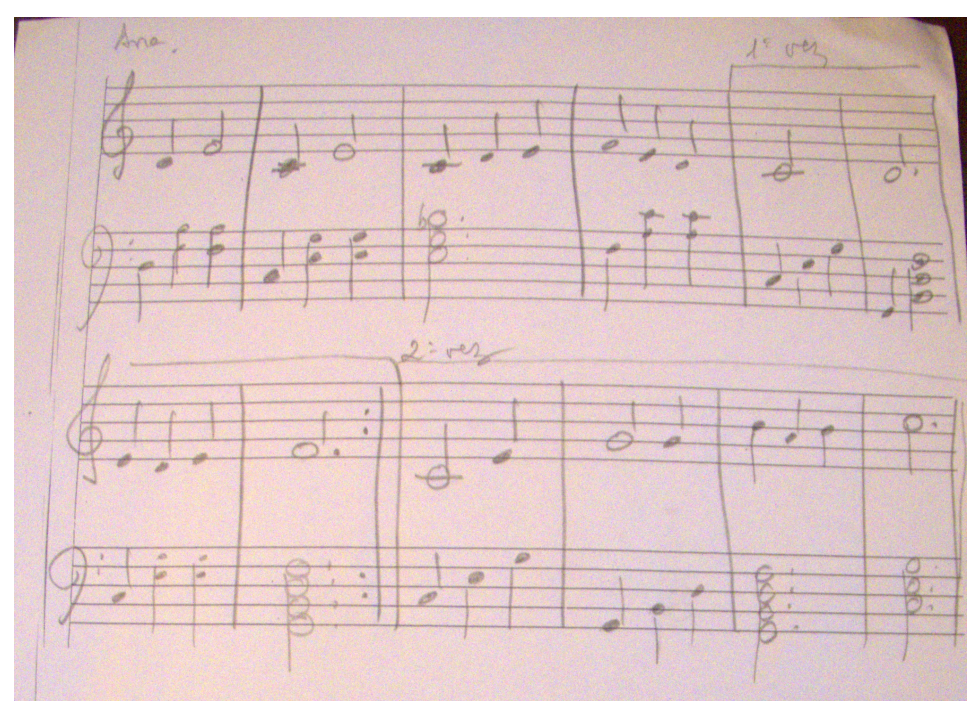


In the case of CP Darío Freán Barreira (37 students), they included an accordion, chimes, percussion and lyrics as shown below in Figure 8.

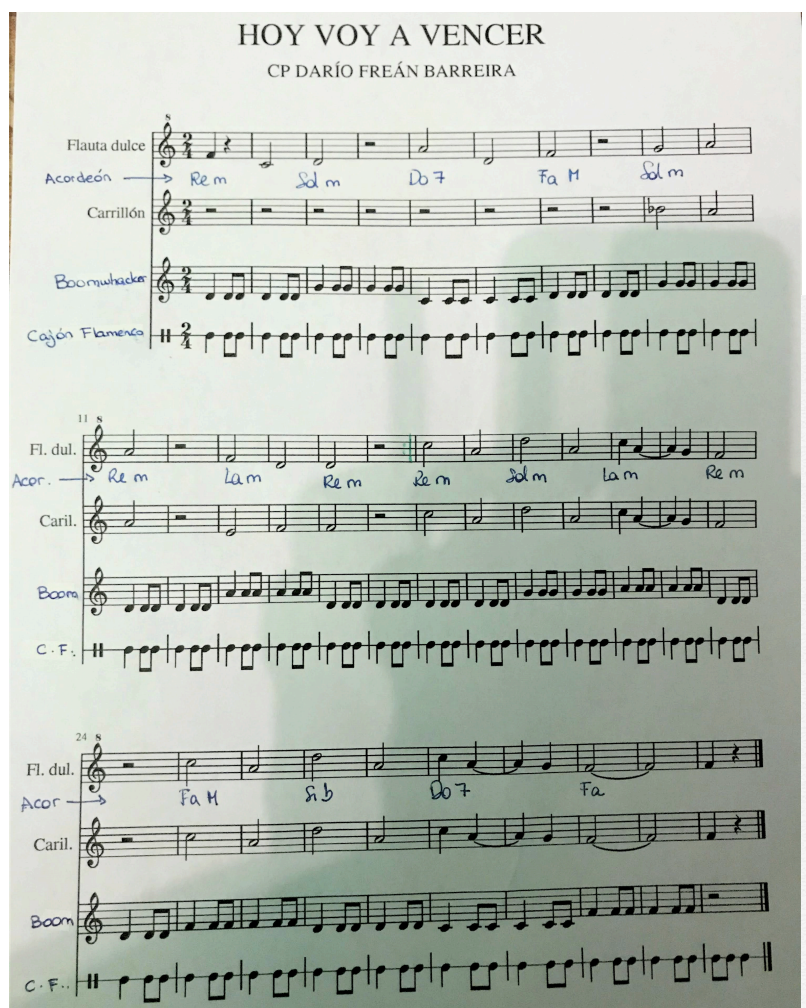

\section{Hoy voy a vencer}

Esta vez voy a vencer

Nada me puede entorpecer

Tengo apoyo y un querer

Que me van a atender

Esta vez voy a vencer

Yo sé que venceré

El poder de investigar Una cura va a crear

Al malo va a rastrear

Para así eliminar

Todos juntos alcanzar

El final de este mal

Ese es la prioridad

Que debemos ya buscar.

Figure 9. Score from IES Bernaldo de Quirós, for Chello and piano (2 students).

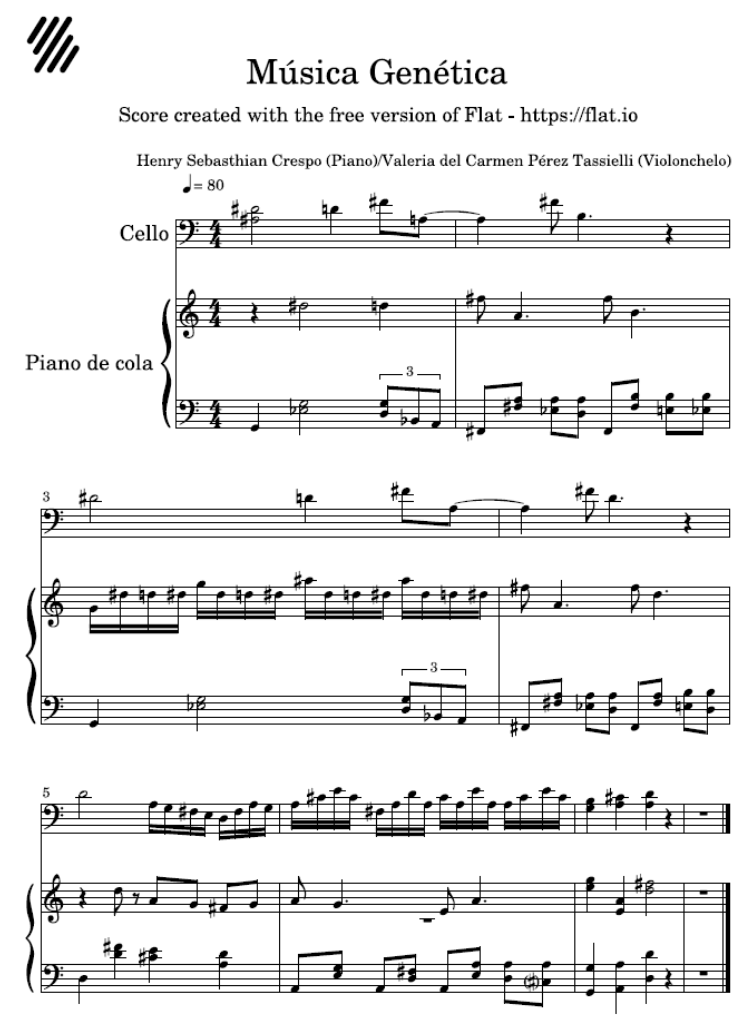


The results of the project were shown last year (November $14^{\text {th }}, 2019$ ) in a public concert. All the videos are freely available at the YouTube channel of the Ministry of Science, Innovation and University of the Asturias Government (Table 2).

Table 2. Links to the musical performances of the different student groups involved in this project.

\begin{tabular}{ll}
\hline School & Link to YouTube video \\
\hline CP La Ería & $\underline{\text { v1B0sPefLu0 }}$ \\
IES Aramo & yIHTXLuHKjg \\
IES Isla de la Deva & $\underline{\text { wR5CcB9bmuE }}$ \\
IES Río Trubia & $\underline{\text { ICpVwCyYcKY }}$ \\
IES Padre Feijóo & $\underline{\text { E9ZoF0r9pRo }}$ \\
IES Bernaldo de Quirós & paX2rV-vxI8 \\
IES Infiesto & $\underline{\text { 7Ynj5IQhJXM }}$ \\
CP Darío Freán Barreira & $\underline{\text { 8wCLJ33l2nY }}$ \\
\hline
\end{tabular}




\section{Discussion}

Relationships between music and science have appeared several times through history. For instance, in the Johann Sebastian Bach's "Crab canon" (Canon 1 a 2, Musical Offering, BWV1079) the main theme is played from the beginning and from the end of the score simultaneously, reminding slightly two DNA strands, or the mechanism of RNA interference. In this sense, Douglas Hofstadter proposed forty years ago that, in simple cases, a molecule of double-stranded DNA is in itself a sort of "molecular crab canon" (for instance the molecule 5'-...TTTTCGAAAA...-3') [2]. The idea to transcribe organic molecules into music is not new. There have been several initiatives such as for instance to associate every DNA base to one note (http://www.geneticmusicproject.com), to use non-coding sequences and other DNA patterns for music generation [3] or even use proteins and their amino acid sequence as a musical source [4].

In spite of these initiatives to associate genetic or biological information with music, none of them have addressed genetic music generation as a STEAM project. Using such an approach, students can learn the genetic code while composing music, but also the relationship between genotype, environment and phenotype. In this way, the same gene (genotype) resulted in different compositions (phenotypes) arising from the work of different groups of students using different notes or musical instruments (environment).

Genetic Music can be used to show the biological sense of genetic mutations as they can lead to melody alterations (Figure 10). A mutation is silent when nucleotide change does not imply note change; on the contrary, if the mutation implies melody change several options come into consideration. For instance, a better melody -of course better/worse are just subjective feelings depending on the person- can be obtained just changing one note. Some mutations are positive to humans, such as the one that led to lactase persistence in Neolithic European populations, which allowed those people to drink milk during adulthood [5]. Note change can end in a different melody, in the same way that some mutations make us different, such as those originating red hair [6]. Finally, worse melodies can appear. Depending on the severity, mutations can alter important molecular functions leading to different diseases with genetic background. Insertional mutations can end in a totally different melody with unexpected biological consequences. Finally, mutations generating a transcriptional stop render truncated and therefore incomplete melodies. Truncated gene products can have lethal effects, but gene interruption can also make us different, such as the case of the European negative Rhesus phenotype [7]. 
Figure 10. Several types of mutations and their effect over the resulting melody. A brief musical piece for piano was composed using the better melody: https://www.youtube.com/watch?v=WlWQoKTFqw8

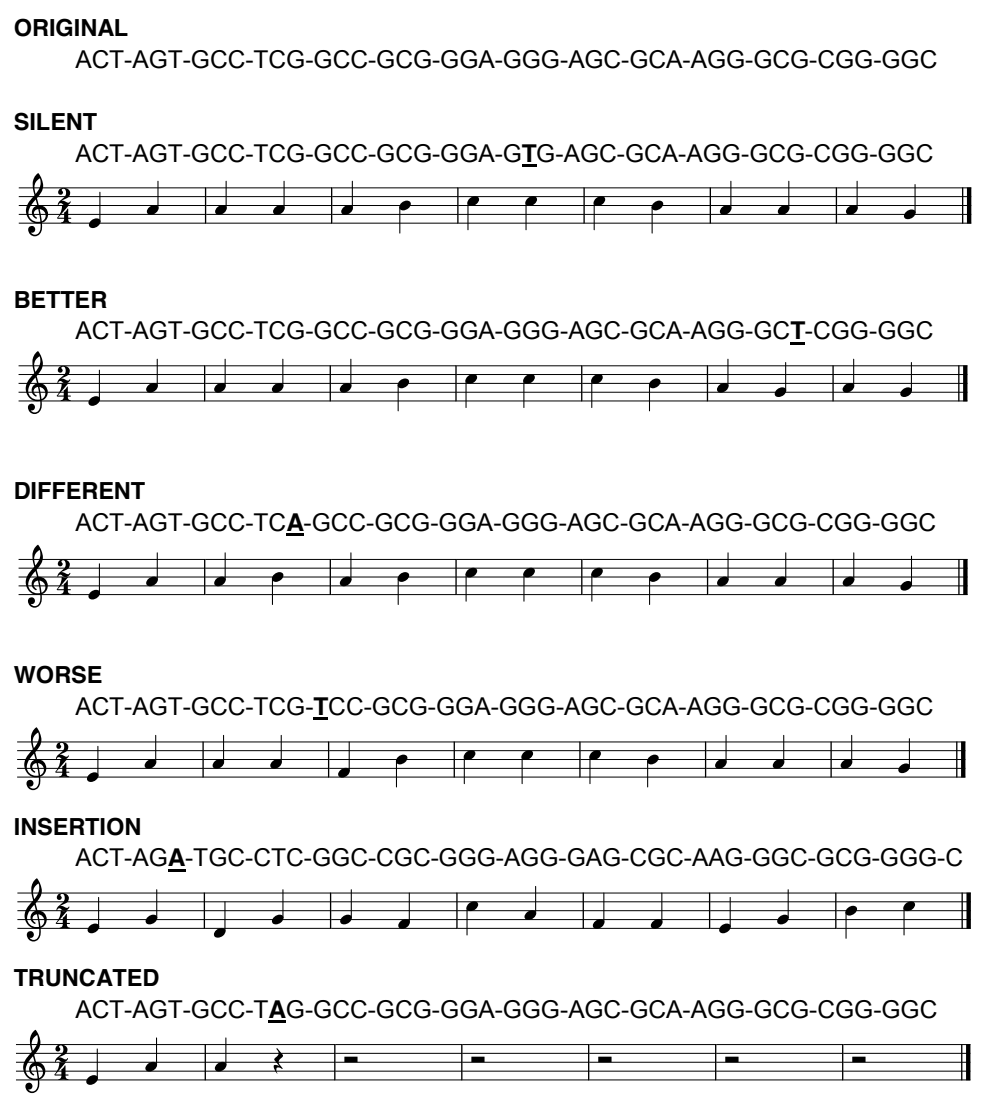

Future genetic music projects based on our approach may include assigning base triplets not only to notes, but to durations (for instance, the triplet AAA could define an A 4 quarter note), introduce accidentals, tie notes, dotted notes, any kind of dynamics and of course rests. This method could also allow advanced applications and automations using the MusicXML format, which can be applied to transcribe whole genomes into complete musical works.

To sum up, Genetic Music is a methodology to connect genetics and music, science and arts, in which genes are transcribed into melodies. Although it has been focused to school students, this activity can be extended to people of any age. The results of this pilot project were performed in a public concert, held in Oviedo the 14th of November 2019, when a group of 155 scholars from eight public schools played their own compositions, all of them arranged around base melodies obtained from the human notch1 gene sequence. This was perhaps one of the first (if not the first) Genetic Music Concert played by students. 


\section{Acknowledgements}

We gratefully acknowledge our colleagues of the Education and Presidence Ministries of the Government of Asturias for their technical support and diffusion of our initiative among the public education community. We thank teachers M.C. Calero, D. Tablón, B. Rivas, C. Vallín, N. Menéndez, Á. González, R. Fernández, I. Acevedo, N. Flaquer, and M. Martínez for all their time and dedication with students. We also thank researchers X.S. Puente and J.M. Freije for providing us with notch1 and CLL information and for all the support during the Genetic Music concert. We sincerely acknowledge all the MARGA Consortium from IES Río Trubia, (Oviedo); IES Padre Feijoo, (Gijón); IES Bernaldo de Quirós, (Mieres); CP La Ería, (Oviedo); CP Darío Freán Barreira, (Jarrio); IES Aramo, (Oviedo) and IES Infiesto, (Infiesto). The authors would highlight that these students employed their school playtime to obtain, orchestrate and practice their own genetic compositions.

Finally, this project is dedicated to the memory of Professor Margarita Salas, our brilliant Asturias scientist. Her passion for science and her work, effort, and perseverance to improve will live among us forever.

\section{References}

[1] Puente, X.S., Pinyol, M., Quesada, V., Conde, L., et al., Whole-genome sequencing identifies recurrent mutations in chronic lymphocytic leukaemia. Nature 2011.

[2] Hofstadter, D.R., Gödel, Escher, Bach: An Eternal Golden Braid. Pp 201-202. Ed. Basic Books. 1979.

[3] Sánchez Sousa, A., Baquero, F., Nombela, C., The making of the Genoma Music. Rev. Iberoam. Micol. 2005.

[4] Yu, C.H., Qin, Z., Martin-Martinez, F.J., Buehler, M.J., A Self-Consistent Sonification Method to Translate Amino Acid Sequences into Musical Compositions and Application in Protein Design Using Artificial Intelligence. ACS Nano 2019.

[5] Itan, Y., Powell, A., Beaumont, M.A., Burger, J., et al., The origins of lactase persistence in Europe. PLoS Comput. Biol. 2009, 5, 17-19.

[6] Rees, J.L., Genetics of Hair and Skin Color. Annu. Rev. Genet. 2003.

[7] Flegel, W.A., The genetics of the Rhesus blood group system, in: Blood Transfusion, 2007.

Supplementary file 1: Genetic card template in Spanish Supplementary file 2: Genetic card template in English 